\title{
Attitude towards obesity and its treatment - analysis of the attitudes of patients with obesity
}

\author{
KRZYSZOF SOBCZAK ${ }^{\mathrm{A}, \mathrm{B}, \mathrm{E}-\mathrm{G}}$, KATARZYNA LEONIUK ${ }^{\mathrm{A}, \mathrm{c}, \mathrm{D}, \mathrm{E}}$ \\ ORCID ID: 0000-0002-8354-2299 ORCID ID: 0000-0001-9802-1771
}

Department of Sociology Medicine \& Social Pathology, Medical University of Gdansk, Poland

A - Study Design, B - Data Collection, C - Statistical Analysis, D - Data Interpretation, E - Manuscript Preparation, F - Literature

Search, G - Funds Collection

Summary Background. Knowledge is one of the key individual measures for prevention and treatment of overweight and obesity. Objectives. We wanted to find out what the attitudes of obese patients towards their own disease were. It was also our goal to identify the sources of knowledge on obesity and learn about their significance in the perception of the disease.

Material and methods. The study was conducted between February and March 2019. 621 patients suffering from obesity participated in it. The study was conducted with the use of the CAWI technique and an original, self-made research tool.

Results. $81.1 \%$ of our respondents revealed that they did not accept their obesity. For the patients, electronic media was the main source of knowledge concerning the disease. $30.4 \%$ of respondents declared that they make use of information obtained from other patients. A similar percentage (30.1\%) stated that they used academic publications. Only $19.2 \%$ received knowledge about the illness from medical staff, most frequently from primary care physicians $(77.8 \%)$, doctors of other specialisations $(74.5 \%)$ and nutritionists (63.2\%). Patients indicated a low level of knowledge concerning patients' rights, possibilities for getting psychological support and rehabilitation during the disease.

Conclusions. Most patients declared a will to start obesity treatment. A large group (30\%) required encouragement to start therapy and obtain support during obesity treatment. Medical staff are in need of information support, thanks to which they will be able to serve as a reliable source of knowledge concerning obesity treatment methods.

Key words: obesity, therapeutics, body weight.

Sobczak K, Leoniuk K. Attitude towards obesity and its treatment - analysis of the attitudes of patients with obesity. Fam Med Prim Care Rev 2020; 22(4): 325-330, doi: https://doi.org/10.5114/fmpcr.2020.100443.

\section{Background}

Obesity is understood as excessive adipose tissue accumulation. One of the traditional methods of obesity assessment is through body mass and height proportion - the Body Mass Index (BMI) introduced by the WHO in 1997 [1, 2]. The criteria that were adopted assumed that for obesity $\mathrm{BMI} \geq 30$. Based on this, the WHO estimates that the weight of 1.9 billion adults exceeds the normal level (39\%). Among them, 650 million (13\%) are patients who suffer from obesity [2]. Eurostat data, on the other hand, shows that $51.6 \%$ of people who live in the $28 \mathrm{EU}$ countries are affected by overweight, while $15.9 \%$ suffer from obesity [3].iln Europe, a million people die every year due to diseases caused by obesity.

In the face of an obesity pandemic, numerous strategies of overweight and obesity risk facto' prevention are being developed on various levels, from modification of social behaviour to individual therapy programmes [4-6]. However, individual awareness concerning critical self-assessment of one's own condition and habits, which constitute key factors for incidences of obesity, remains the basis of effective prevention and treatment [7]. Therefore, an analysis of the knowledge and behaviour of patients with obesity became the purpose of our research. We wanted to know the attitudes of the patients who suffer from obesity towards their own disease. As far as their knowledge is concerned, we were interested in the role of medical staff and the activities the patients with obesity undertaken as a part of treatment.

\section{Objectives}

An analysis of knowledge and behaviour of patients who suffer from obesity became our goal. We wanted to find out what attitudes towards the disease could be observed among those who suffer from obesity. When it comes to sources of knowledge, we were interested in the role of medical staff and activities undertaken by patients with obesity as a part of therapeutic measures. We would like the data we have obtained to contribute to future educational programmes which would take into account the actual needs of patients who suffer from obesity. The results of our study could also be useful for outlining educational guidelines for medical staff. Improving patients' knowledge may not only prove significant in dealing with the disease, but it may also increase satisfaction from health services.

\section{Material and methods}

The presented results are a fragment of the analyses of a national study concerning the experience of patients who suffer from obesity in their contacs with medical staff. The main study was conducted in the period from February 2018 to March 2019. The data was obtained with the use of the CAWI technique (Computer-Assisted Web Interview). The research tool was an original, self-made survey questionnaire, which was digilised and placed on a professional website for conducting sociological studies (www.e-badania.pl). The highld standardised survey consisted of 20 closed-ended and semi-open questions, as well as 8 demographic questions. The Likert scale was used for the self-assessment of knowlednt. In the assessment of the relations with medical staff, a nominal scale was used (mainly the yes/no type). The tool was prepared by sociologiss, according to the methodology used in social sciences, which takes 


\begin{tabular}{|c|c|c|c|}
\hline Categories & $n(\%)$ & Categories & $n(\%)$ \\
\hline $\begin{array}{l}\text { Gender } \\
\text { women } \\
\text { men }\end{array}$ & $\begin{array}{l}547(88) \\
74(12)\end{array}$ & \multirow{2}{*}{$\begin{array}{l}\text { Status of intimate relationships } \\
\text { single } \\
\text { married } \\
\text { in an informal relationship } \\
\text { divorced/separated } \\
\text { widow/widower }\end{array}$} & \multirow{2}{*}{$\begin{array}{l}141(22) \\
330(53) \\
99(16) \\
36(7) \\
15(2)\end{array}$} \\
\hline \multirow{2}{*}{$\begin{array}{l}\text { Education } \\
\text { primary } \\
\text { junior high school } \\
\text { vocational secondary education } \\
\text { secondary school education } \\
\text { higher education }\end{array}$} & \multirow{2}{*}{\begin{tabular}{|l}
$9(1.5)$ \\
$6(1)$ \\
$32(5)$ \\
$217(35)$ \\
$357(57.5)$ \\
\end{tabular}} & & \\
\hline & & \multirow{2}{*}{$\begin{array}{l}\text { Age } \\
\qquad \begin{array}{l}18-29 \text { years old } \\
30-45 \text { years old } \\
46-60 \text { years old } \\
61 \text { years old or more }\end{array}\end{array}$} & \multirow{2}{*}{$\begin{array}{l}107(17) \\
344(56) \\
150(24) \\
20(3) \\
\end{array}$} \\
\hline \multirow{2}{*}{$\begin{array}{l}\text { Subjective impression of one's condition } \\
\text { very good } \\
\text { rather good } \\
\text { rather bad } \\
\text { very bad } \\
\text { neither good nor bad }\end{array}$} & \multirow{2}{*}{$\begin{array}{l}33(5) \\
350(56.5) \\
145(23.5) \\
21(3.5) \\
72(11.5)\end{array}$} & & \\
\hline & & \multirow{2}{*}{$\begin{array}{l}\text { Age at which obesity developed } \\
\text { childhood } \\
\text { adolescence } \\
\text { early adulthood } \\
\text { middle adulthood ( } 35-49 \text { years old) } \\
\text { late adulthood (50-64 years old) } \\
\text { advanced age (64-74 years old) } \\
\end{array}$} & \multirow{2}{*}{$\begin{array}{l}289(465) \\
111(18) \\
15(25) \\
59(9.5) \\
7(1) \\
1(0) \\
\end{array}$} \\
\hline \multirow{2}{*}{$\begin{array}{l}\text { Accompanying conditions } \\
\text { cancer } \\
\text { respiratory diseases } \\
\text { nervous system diseases } \\
\text { endocrine gland disorders } \\
\text { blood and cardiovascular diseases } \\
\text { musculoskeletal diseases } \\
\text { genitourinary diseases } \\
\text { mental and behavioural disorders } \\
\text { skin diseases } \\
\text { eye diseases } \\
\text { other }\end{array}$} & \multirow[b]{2}{*}{\begin{tabular}{|l}
$8(1)$ \\
$42(7)$ \\
$14(2)$ \\
$231(37)$ \\
$185(30)$ \\
$68(11)$ \\
$47(7.5)$ \\
$36(6)$ \\
$11(1.5)$ \\
$6(1)$ \\
$34(5)$
\end{tabular}} & & \\
\hline & & $\begin{array}{l}\text { Declared causes for the respondents' obesity } \\
\text { genetic factors } \\
\text { hormonal factors } \\
\text { pharmacological treatment } \\
\text { lifestyle } \\
\text { stress } \\
\text { ageing } \\
\text { unknown cause } \\
\text { other }\end{array}$ & $\begin{array}{l}55(9) \\
71(11.5) \\
25(4) \\
256(41) \\
129(21) \\
1(0) \\
77(12.5) \\
7(1)\end{array}$ \\
\hline
\end{tabular}

into account the rules and principles which are appropriate for a study of this type. The first version of the survey was tested in a pilot study. We also conferred with the Commissioner for the Rights of Patients Suffering from Obesity.

\section{Data collection}

The first manner of informing respondents about the possibility to participate in the study was through adverts and information in electronic media. Patients could also find out about the possibility to participate in the study through information leaflets which were made available by medical institutions and support groups for patients suffering from obesity. When the study started, the respondents were informed that they could abandon the study at any point.

The survey was aimed at people who live in Poland. A BMI of at least 30 was another inclusion criterion. To verify this, the respondents were asked about their body mass and height. A total number of 684 respondents participated in the survey, while $90.8 \%$ of the surveys (the statements of 621 patients) were qualified for analysis (Table 1). The statements of 63 participants were rejected as they failed fulfil the inclusion criterion, meaning their BMI was lower than 30 .

\section{Statistical analysis}

The gathered data was processed in the form of summary statistics with the use of IBM SPSS v. 26 software. Pearson's chi-squared test was used for analysing the correlation between discontinuous variables and the statistic heterogeneity of the groups. A difference of $p<0.05$ was assumed as statistically important.

\section{Ethical approval}

The project received the approval of the Independent Bioethics Commission for Research at the Medical University of Gdansk (KNBBN/589/2017/2018).

\section{Results}

\section{Patients' attitude to obesity and its treatment}

An analysis of the respondents' attitude to their own disease was the first interesting issue for us. Over half of the patients who participated in our study $(52 \%)$ stated that they did not accept their own obesity and therefore would like to start treating it. Almost one in three respondents $(29.1 \%)$ revealed that he or she did not accept his or her obesity, in spite of the awareness that it had a negative impact on his or her health and self-esteem but, in his or her opinion, starting treatment was too difficult and ineffective. A fifth of the patients admitted that they accepted their obesity. $1 \%$ of them did not intend to undertake any therapeutic activities, while the remaining $17.9 \%$ were interested in therapy due to their disease's impact on their health.

We divided the patients into two groups. The first consisted of respondents who declared acceptance for their obesity (18.9\%). There were people who did not accept their disease in the other group (72.1\%). In spite of the fact that most of the respondents had not come to terms with their obesity, such an attitude was indicated more frequently by people who suffered from many chronic diseases than people for whom obesity was the sole disease $\left(76.9 \%\right.$, statistics: $\left.\mathrm{chi}^{2}=4.027 ; d f=1 ; p<0.045\right)$.

Among the chronically ill, as many as $83.5 \%$ did not accept their obesity. In the group of respondents with no other chronic diseases, the fraction of those who did not accept their body mass was lower and amounted to $76.9 \%$. Similarly, among the respondents who assessed their condition as "rather bad and very bad" and "neither good nor bad", there were more of those who did not accept their obesity (86.6\%) compared to respondents who assessed their general condition as "very good or rather good" (77.8\%).

We focused on the group of respondents (29\%) who declared that they did not accept their obesity but believed that starting treatment was too difficult and would not bring the desired effects. This view was most frequently expressed by the older respondents (at the age of 46 or more) and people who 
assessed their general condition as "rather bad and very bad" or "neither good nor bad". Apart from that, we noticed that people who named lifestyle as the main cause of obesity were less likely to declare the above-mentioned attitude towards obesity (Table 2).

Among the older respondents (46 years old or more), every third person (35.3\%) did not accept his or her obesity and was sceptical about its treatment, while among the younger respondents (18-45 years old), every forth respondent agreed with this view. People who indicated lifestyle as the main cause for their obesity (23.4\%) were less likely to define their attitude to their disease as lack of acceptance and reluctance towards treatment than those who chose non-behavioural factors (33.2\%). sity from other patients (30.4\%) or from academic publications (30.1\%). It should be pointed out that only one in four respondents (19.2\%) indicated medical staff as a significant source of knowledge on obesity, while one in six respondents extended his or her knowledge thanks to patient organisations (15.3\%).

\section{Medical staff as a source of knowledge about the disease}

In spite of the fact that only every fifth respondent indicated medical staff as a significant source of information about obesity, most of the respondents $(79.5 \%)$ had a chance to discuss their disease with members of medical staff. One in five respon-

\begin{tabular}{|c|c|c|c|c|}
\hline & $\begin{array}{l}\text { Total } \\
n(\%)\end{array}$ & $\begin{array}{l}\text { Lack of obesity acceptance and } \\
\text { unwillingness to treat it } \\
n(\%)\end{array}$ & $\begin{array}{l}\text { People who accept their obesity } \\
\text { and/or want to start treatment } \\
n(\%)\end{array}$ & $p$ \\
\hline $\begin{array}{l}\text { Age } \\
18-45 \text { years old } \\
46 \text { or more }\end{array}$ & $\begin{array}{l}451(73) \\
170(27)\end{array}$ & $\begin{array}{l}121(27) \\
60(35)\end{array}$ & $\begin{array}{l}330(73) \\
110(65)\end{array}$ & 0.038 \\
\hline $\begin{array}{l}\text { Main cause of obesity } \\
\text { lifestyle } \\
\text { other causes }\end{array}$ & $\begin{array}{l}385(62) \\
236(38)\end{array}$ & $\begin{array}{l}107(28) \\
74(31)\end{array}$ & $\begin{array}{l}278(72) \\
162(69) \\
\end{array}$ & 0.009 \\
\hline $\begin{array}{l}\text { Self-assessment of general condition } \\
\text { very good and rather good } \\
\text { rather bad or very bad or neither } \\
\text { good nor bad }\end{array}$ & $\begin{array}{l}383(62) \\
238(38)\end{array}$ & $\begin{array}{l}91(24) \\
90(38)\end{array}$ & $\begin{array}{l}292(76) \\
148(62)\end{array}$ & 0.004 \\
\hline
\end{tabular}

\begin{tabular}{|c|c|c|c|c|c|}
\hline \multirow[t]{2}{*}{ Categories } & \multicolumn{5}{|c|}{ Level of knowledge $n(\%)$} \\
\hline & very high & rather high & rather low & very low & no knowledge \\
\hline Causes of obesity & $198(32)$ & $323(52)$ & $72(12)$ & $21(3)$ & $7(1)$ \\
\hline $\begin{array}{l}\text { Medical diagnostics concerning the causes of } \\
\text { obesity (genetic testing, hormonal disorders, } \\
\text { etc.) }\end{array}$ & $78(13)$ & $225(36)$ & $183(29)$ & $74(12)$ & $61(10)$ \\
\hline Psychological conditionings of obesity & $136(22)$ & $238(38)$ & $137(22)$ & $59(10)$ & $51(8)$ \\
\hline $\begin{array}{l}\text { Health consequences of obesity (diseases } \\
\text { which are complications resulting from } \\
\text { obesity) }\end{array}$ & $252(41)$ & $298(48)$ & $46(7)$ & $18(3)$ & $8(1)$ \\
\hline Rights of patients with obesity & $23(4)$ & $45(7)$ & $202(32)$ & $142(23)$ & $209(34)$ \\
\hline Obesity treatment methods & $124(20)$ & $229(37)$ & $133(13)$ & $82(13)$ & $33(5)$ \\
\hline Availability of psychological assistance & $48(8)$ & $104(17)$ & $182(29)$ & $142(23)$ & $145(23)$ \\
\hline $\begin{array}{l}\text { Self-help groups gathering people with } \\
\text { obesity }\end{array}$ & $62(10)$ & $105(17)$ & $153(25)$ & $125(20)$ & $176(28)$ \\
\hline Rehabilitation for people with obesity & $18(3)$ & $49(8)$ & $145(23)$ & $145(23)$ & $264(43)$ \\
\hline
\end{tabular}

\section{Patients' knowledge on obesity and its sources}

To measure the help potential, we asked the respondents to provide a subjective assessment of the level of their own knowledge concerning obesity (Table 3 ). The largest number of respondents said the level of their knowledge concerning the health consequences of obesity $(40.6 \%)$ and the causes of obesity $(31.9 \%)$ was very high. A very low level of knowledge was declared by respondents when it came to rehabilitation for people with obesity (23.3\%), the possibility of getting psychological support (22.9\%), as well as the rights of patients who suffer from obesity (22.9\%).

Electronic media was the main source of knowledge concerning obesity. Among this, websites (83.7\%) and online forums (39.9\%) were the most popular. Blogs (17.1\%), as well as YouTube channels run by people suffering from obesity $(5.5 \%)$, were mentioned less frequently. Less than one third of the respondents declared that he or she gets information about obe- dents $(20.5 \%)$ said that he or she had not talked to medical staff about his or her obesity at all.

Most of the respondents had discussed their obesity with their primary care physician $(77.8 \%)$ and/or a specialist consultant $(74.5 \%)$. Among the most frequently indicated specialist consultants, there were: endocrinologists, surgeons, bariatrists, psychiatrists, gynaecologists, diabetes specialists, orthopaedists and cardiologists. Two thirds of the respondents had talked to a nutritionist (63.2\%), while one third to a psychologist (36.2\%).

As a part of the therapeutic logistics analysis, we asked the participants of the study about the degree of their adherence to the recommendations of medical staff. Most of the respondents (92.7\%) declared that they had been abiding by the recommendations of the medical staff. Every second of these respondents (51.4\%) had completed all the orders he or she had received. Only one in fourteen participants (7.3\%) admitted that he or she had ignored the medical specialist's recommendations. 


\section{Actions undertaken by patients to treat obesity}

It is worth emphasising that seven out of ten respondents $(69.9 \%)$ declared that they wanted to start obesity treatment $(n=621)$. The activities aiming at body mass reduction undertaken the most frequently were: unassisted diet change, which had been applied by most of the respondents (98.4\%), and unassisted increase in physical activity, undertaken by $91.5 \%$ of the respondents. Consulting a nutritionist may be considered a popular method of fighting obesity. $78 \%$ of the respondents had done this. The least popular obesity treatment methods (Table 4) were: participation in support groups for people with obesity $(29.3 \%)$ and receiving psychological support or therapy (29.7\%).

\begin{tabular}{|c|c|c|c|}
\hline \multirow[t]{2}{*}{ Kinds of actions } & \multicolumn{3}{|c|}{ Assessment $n(\%)$} \\
\hline & $\begin{array}{l}\text { yes, cur- } \\
\text { rently }\end{array}$ & $\begin{array}{l}\text { yes, in the } \\
\text { past }\end{array}$ & $\begin{array}{l}\text { they have } \\
\text { not been } \\
\text { undertaken }\end{array}$ \\
\hline $\begin{array}{l}\text { Unassisted change of } \\
\text { diet }\end{array}$ & $251(40)$ & $360(58)$ & $10(2)$ \\
\hline $\begin{array}{l}\text { Change of diet super- } \\
\text { vised by a nutritionist }\end{array}$ & $103(17)$ & $381(61)$ & $137(22)$ \\
\hline $\begin{array}{l}\text { Unassisted increase in } \\
\text { physical activity }\end{array}$ & $246(40)$ & $322(52)$ & $53(8)$ \\
\hline $\begin{array}{l}\text { Participation in physical } \\
\text { activity with a trainer }\end{array}$ & $40(6.5)$ & $177(28.5)$ & $104(65)$ \\
\hline $\begin{array}{l}\text { Medical diagnostics of } \\
\text { causes of obesity }\end{array}$ & $130(21)$ & $168(27)$ & $323(52)$ \\
\hline $\begin{array}{l}\text { Use of diet supple- } \\
\text { ments which reduce } \\
\text { body mass }\end{array}$ & $35(6)$ & $410(66)$ & $176(28)$ \\
\hline $\begin{array}{l}\text { Use of pharmaceuti- } \\
\text { cal drugs prescribed } \\
\text { or recommended by } \\
\text { a doctor }\end{array}$ & $64(18)$ & $267(43)$ & $290(47)$ \\
\hline $\begin{array}{l}\text { Surgical obesity treat- } \\
\text { ment }\end{array}$ & $230(37)$ & $56(9)$ & $335(54)$ \\
\hline $\begin{array}{l}\text { Psychological support } \\
\text { or therapy }\end{array}$ & $83(13.5)$ & $101(16)$ & $437(70.5)$ \\
\hline $\begin{array}{l}\text { Participation in support } \\
\text { groups }\end{array}$ & $117(18)$ & $65(10)$ & $439(71)$ \\
\hline $\begin{array}{l}\text { Active participation in } \\
\text { online forums dedi- } \\
\text { cated to the problems } \\
\text { of people suffering } \\
\text { from obesity }\end{array}$ & $233(38)$ & $102(16)$ & $286(46)$ \\
\hline
\end{tabular}

\section{Discussion}

Obesity is a disease entity and the third risk factor when it comes to the occurrence of serious diseases, right after hypertension and addiction to nicotine. It is estimated that it is the cause of $10-13 \%$ of deaths in Europe [8]. Research shows that there is relatively high social awareness concerning the general perception of obesity as a serious disease. Ślusarska et al. claim that according to polls, as many as $82 \%$ of respondents consider obesity a serious disease [9]. The current research by Wyleżoł et al., who have analysed Poles' knowledge concerning obesity, shows that the level of social awareness concerning the results of complications connected with obesity is extremely high (91\%). Over half of the respondents (55.3\%) had accurate knowledge concerning the causes of obesity, while only $39.8 \%$ of patients knew the proper obesity treatment methods [10]. As far as the applicable guidelines for measures connected with obesity in adults are concerned, it must be understood that the therapeutic process is a multi-faceted one, and its elements range from recommendations concerning diet and physical activity through cognitive behavioural therapy (CBT), psychological support and pharmacological treatment to bariatric surgery [6]. However, similarly to the publication by Wyleżoł et al., our results have revealed that patients do not have a sufficient level of detailed knowledge which would refer to other methods of treatment than diet modification or physical activity [10]. Such a stance was confirmed by Manasterski et al., who pointed out an especially low level of knowledge in middle-aged men from rural areas [7]. In our research, the most frequent measures taken by patients to reduce weight were an unassisted change of diet (98.4\%) and additional physical activity (91.5\%). Less than half of the respondents underwent medical diagnostics. Less than $30 \%$ of the respondents stated that they had taken part in support groups and psychological therapy. At the same time, $52 \%$ of the respondents admitted that they did not accept their obesity and wanted to start treating it. $29.1 \%$ revealed that they did not accepted their disease and believed that obesity has unfavourable health and emotional inclinations. However, they have not undertaken therapeutic measures, as they do not believe in their effectiveness. In reference to the above--mentioned problems, we asked our respondents about their subjective assessment of their knowledge connected with obesity. Slightly above $40 \%$ of the patients admitted that, according to their assessment, the level of their knowledge was very high or rather high. Over $40 \%$ of the respondents stated that the causes of obesity had to be sought in lifestyle, while almost $21 \%$ thought that obesity was caused by stress or other psychosocial conditionings. Almost $9 \%$ of the respondents indicated genetic factors, while $11.5 \%$ indicated hormonal causes. Though our results were very divergent quantitatively when compared to those obtained by NowickaSauer et al., who researched the perception of the disease in patients with obesity, when it comes to the analysis of conclusions, we can point to their similarity. Above all, the patients see the cause of their obesity in factors which are under their control, rather than those which are independent of them [11].

Referring to the sources of knowledge concerning their disease, the patients who participated in our study indicated electronic media as the base of their knowledge. Patients provided high self-evaluations of their knowledge concerning the causes of obesity, diagnostic methods, conditionings and consequences of the disease, as well as treatment methods. The patients indicated insufficient knowledge concerning the rights of patients with obesity, as well as the possibility to get psychological support and rehabilitation.

Though most of the patients who participated in our survey (79.5\%) had talked to a doctor about their obesity, only every fifth patient indicated medical staff as an important source of information. It seems to us that there is a unique relation in this field. On the one hand, it pertains to the studied group and the applied CAWI technique, which is characterised by an overrepresentation of women with higher education, most of whom live in large cities. Therefore, socio-demographically, this is a group of people who use electronic media on daily basis. On the other hand, an assumption could be made which seems very likely in the face of many research reports that medical staff need support when it comes to knowledge connected with obesity treatment methods and informing patients about them [12-15]. Public health experts emphasise the fact that providing information and education, as well as dedicated systemic solutions aimed at patients, are of particular significance in preventing and treating obesity $[4,9,16]$. The low level of knowledge in patients does correlate with bad habits, which are the most frequent factor in obesity prevention and treatment [17]. In this context, less than $16 \%$ of the patients confirmed that they had been given information concerning additional sources of knowledge about the disease. Only one in five patients reported that he or she had received information about the possibility of obesity treatment conducted by a team of specialists and the possibility to receive psychological support. The results that were obtained 
seem particularly significant in the case of primary care physicians. We believe that it is necessary to introduce an obligation for primary care physicians to analyse BMI at least twice a year. In our opinion, primary care physicians need assistance when it comes to the knowledge of obesity treatment methods. Communication reduced to providing information about the need to change one's diet and increase physical activity is insufficient from the obesity treatment perspective.

It must be emphasised that the research method which was adopted, and the main inclusion criterion might have had an impact on the results that were received. The inclusive selection of the respondents, which results in a lack of representation, is one of the disadvantages of the technique which was adopted (CAWI). This resulted in an overrepresentation of women and people under 45 with higher education who live in larger cities. Another problem connected with the use of online techniques is the limited selection of respondents resulting from access to the Internet. We also assumed that the basic inclusion criterion would be a $\mathrm{BMI}$ of $\geq 30$. However, we were fully aware that using the anthropometric criterion is not free from disadvantages. Firstly, BMI cannot be an ultimate diagnostic result but merely a signal which requires additional verification, as it does not take into account the muscle and bone mass, the patient's age or ethnical provenience, which has a significant impact in reference to the patients' gender. The analyses of the measurements show that in declarative surveys, patients tend to overestimate their height (men on average by $2.1 \mathrm{~cm}$ and women by $2.8 \mathrm{~cm}$ ) and underestimate their weight (men on average by $1.5 \mathrm{~kg}$ and women by $1.9 \mathrm{~kg}$ ), which leads to BMI underestimation by 1.1 points in men and 1.5 in women $[18,19]$. Although we were aware of the BMI criterion's imperfection, we decided it was relatively the best way of remote obesity assessment. It is also a widely accepted index that most studies refer to, which makes a universal result comparison possible.

\section{Conclusions}

1. The Internet is the main source of knowledge concerning obesity, especially websites and online forums dedicated to the disease. Only one in five respondents thought that medical staff were a significant source of knowledge concerning their disease.

2. To reduce body mass, people with obesity most frequently change their diets on their own and increase physical activity. Every seventh patient declared that he or she wanted to use the help of a nutritionist.

3. Most patients declared a will to start obesity treatment. The remaining $30 \%$ required encouragement to start therapy and support during obesity treatment.

4. A significant majority declared that they do not accept their obesity. Such an attitude is observed more frequently in chronically ill patients and in those who see their general condition as bad or neither good nor bad.

5. Medical staff need information support so that they are able to serve as a reliable source of knowledge concerning obesity treatment methods.

Acknowledgements. We would like to express our gratitude to all of the following institutions and associations for their help and support in conducting the research: the Ombudsman, the Commissioner for Patient's Rights, the Polish Association for the Study on Obesity (Polskie Towarzystwo Badań nad Otyłościa), Association of Bariatric Patients (Stowarzyszenie Pacjentów Bariatrycznych), as well as the media patron "poradnikzdrowie.pl".

Source of funding: This work was funded from the authors' own resources.

Conflicts of interest: The authors declare no conflicts of interest.

\section{References}

1. Kanazawa M, Yoshiike N, Osaka T, et al. Criteria and classification of obesity in Japan and Asia-Oceania. World Rev Nutr Diet 2005; 94: 1-12, doi: 10.1159/000088200.

2. Pi-Sunyer X. Obesity: criteria and classification. Proc Nutr Soc 2000; 59(4): 505-509, doi: 10.1017/s0029665100000732.

3. Eurostat. Obesity rate by body mass index (BMI). Available from URL: https://ec.europa.eu/eurostat/tgm/graph.do?tab=graph\&plugin $=1 \&$ pcode=sdg_02_10\&language $=$ en\&toolbox $=$ data.

4. Brzeziński M, Jankowski M, Kamińska B. Skuteczność wybranych medycznych i pozamedycznych metod prewencji i ograniczenia występowania nadwagi i otyłości. Endokrynologia, Otyłość i Zaburzenia Przemiany Materii 2012; 8(4): 114-123.

5. Ramos Salas X. The ineffectiveness and unintended consequences of the public health war on obesity. Can J Public Health 2015; 106(2): e79-81, doi: 10.17269/cjph.106.4757.

6. Tsigos C, Hainer V, Basdevant A, et al. Postępowanie w otyłości dorosłych: europejskie wytyczne dla praktyki klinicznej. Endokrynol Otył Zab Przem Mat 2009; 5(3): 87-98.

7. Manasterski S, Sławin A, Dawiec M, et al. Świadomość zdrowotna i samoocena w zakresie otyłości i nadwagi pacjentów praktyk lekarza rodzinnego. Fam Med Prim Care Rev 2014; 16(3): 257-259.

8. Zgliczyński SW. Nadwaga i otyłość w Polsce. Infros 2017; 4(227): 1-4. Available from URL: http://orka.sejm.gov.pl/WydBAS.nsf/0/E107 6D55B37A9603C12580E2002F7655/\$file/Infos_227.pdf:.

9. Ślusarska B, Szcześniak E, Zarzycka D, et al. Wiedza i opinie osób studiujących na temat problemów związanych z otyłością. Med Og Nauk Zdr 2014; 20(2): 229-234.

10. Wyleżoł H, Omelańczuk I, Radziszewski M, et al. Ocena wiedzy Polaków na temat otyłości - badanie wstępne. Forum Zab Metabol 2017; 8(1): $36-45$.

11. Nowicka-Sauer K, Obara-Gołębiowska M, Pietrzykowska P, et al. Percepcja przyczyn nadwagi wśród pacjentów oddziału leczenia otyłości-raport wstępny. Fam Med Prim Care Rev 2016; 16(3): 269-270.

12. Thuan JF, Avignon A. Obesity management: attitudes and practices of French general practitioners in a region of France. Int $J$ Obes (Lond) 2005; 29(9): 1100-1106, doi: 10.1038/sj.ijo.0803016.

13. Fogelman $\mathrm{Y}$, Vinker S, Lachter J, et al. Managing obesity: a survey of attitudes and practices among Israeli primary care physicians. Int J Obes Relat Metab Disord 2002; 26(10): 1393-1397.

14. Brown I, Stride C, Psarou A, et al. Management of obesity in primary care: nurses' practices, beliefs and attitudes. J Adv Nurs 2007; 59(4): 329-341, doi: 10.1111/j.1365-2648.2007.04297.x.

15. Campbell K, Crawford D. Management of obesity: attitudes and practices of Australian dietitians. Int J Obes Relat Metab Disord 2000; 24(6): 701-710.

16. Pratt CA, Nosiri UI, Pratt CB. Michigan physicians' perceptions of their role in managing obesity. Percept Mot Skills 1997; 84(3): 848850, doi: 10.2466/pms.1997.84.3.848. 
17. Zandstra EH, de Graaf C, Van Staveren WA. Influence of health and taste attitudes on consumption of low- and high-fat foods. Food Quality and Preference 2001; 12(1): 75-82.

18. Michoń P. Otyłość i nadwaga a jakość życia Polaków. Stud Ekonom Zesz Nauk Uniw Ekonom w Katowicach 2014; 179: 51-62.

19. Danubio ME, Miranda G, Vinciguerra MG, et al. Comparison of self-reported and measured height and weight: implications for obesity research among young adults. Econ Hum Biol 2008; 6(1): 181-190, doi: 10.1016/j.ehb.2007.04.002.

Tables: 4

Figures: 0

References: 19

Received: 5.04.2020

Reviewed: 21.04 .2020

Accepted: 28.05.2020

Address for correspondence:

Krzysztof Sobczak, PhD

Zakład Socjologii Medycyny i Patologii Społecznej

Gdański Uniwersytet Medyczny

ul. Tuwima 15

80-210 Gdańsk

Polska

Tel.: +48 58 349-15-53

E-mail: ksobczak@gumed.edu.pl 